\title{
Waiting Times and Defining Customer Satisfaction
}

\section{T.M.B. Palawatta}

University of Sri Jayewardenepura, Sri Lanka

\begin{abstract}
Review of literature shows that there is no agreement about the definition of probably the most important, variable Satisfaction/Dissatisfaction. Satisfaction /Dissatisfaction equals Expectation minus Perception is the most widely used definition today. In this definition, there are a number of issues that have to be resolved. First, what exactly Satisfaction is? Is it disconfirmation? That is the gap between expectation and perception. Is it expectation? Or, is it perception? Further, there is no concrete definition about the expectation. Is it predicted service? Is it adequate service? In this study, the definition of satisfaction/dissatisfaction was tested using continuous variables expected waiting time, perceived waiting time, prior predicted waiting time, posterior predicted waiting time and the acceptable waiting time. Study found that disconfirmation between expected waiting time and the perceived waiting time is the best definition for satisfaction/dissatisfaction followed by expected waiting time and perceived waiting time. However, the influence of perceived waiting time is nearly negligible. Therefore, defining satisfaction/dissatisfaction as disconfirmation between expectation and perception is most appropriate. Furthermore, the study found that expectation is not prediction and is also not the acceptable (adequate) service.
\end{abstract}

\section{Keywords}

Expectation, Perception, Satisfaction, Waiting Time

\section{Introduction}

Objective of this study is to empirically test the definition of customer satisfaction/dissatisfaction with the service. Davis and Heineke (1998) have tested the definition of satisfaction using

\section{Corresponding Author:}

T.M.B. Palawatta, Department of Decision Sciences, University of Sri Jayewardenepura, Nugegoda, Sri Lanka. E-mail: bandulap777@yahoo.co.uk 
waiting times and they found that perceived waiting time explains satisfaction better than both disconfirmation and expectation. This argument is supportive of the suggestion of (Teas, 1993; Cronin \& Taylor, 1994) that measuring perception is sufficient. But others (Anderson, 1973; Parasuraman et al., 1994) argue in favour of disconfirmation model. Further definition of Lord Buddha on the suffering is also in favour of the disconfirmation model. Therefore, empirically testing the definition of satisfaction/dissatisfaction is important to resolve the definitional dispute. Satisfaction is critical for other customer behaviours such as loyalty and other consumer reactions.

This research is important from many points of view. First the satisfaction is the most important variable for a management practitioner. Organizations need to satisfy customers all the times to assure long term survival. Second, clarification of customer behaviour is important. Are they expectation driven? Are they perception driven? Are they disconfirmation driven? Third, expectation and perception variables were measured as continuous variables and this is a rare situation where we get a chance to include continuous variables to measure expectation and perception where we normally are compelled to measure these variables in a category scale. This paper is divided in to two broad areas.

1. Defining customer satisfaction

2. Defining customer expectation

\section{Customer Satisfaction Literature}

Customer satisfaction/dissatisfaction has become an important issue for management practitioners. In fact it is the central theme in management today. Customer satisfaction usually relates to long term use of a good or results of a service, so its evaluation is based on comparisons over considerable time, with customer's perception of competitive offerings. Customer satisfaction studies have focused on three streams (1) variations on the expectancy disconfirmation models; (2) other perspectives of interest including equity and; (3) models extending satisfaction to the redress process (Oliver \& DeSarbo, 1988).

\section{Expectancy Disconfirmation}

Expectancy disconfirmation has its origin in organizational behaviour (Ilgen, 1971) and social psychology (Weaver \& Brickman, 1974). It is actually two processes consisting of the formation of expectations and the disconfirmation of those expectations through performance comparisons. As presented by Oliver (1980) consumers are believed to form expectations of product performance characteristics prior to purchase. Subsequent purchase and usage reveal actual performance levels that are compared to expectation levels using a better-than, worse-than, heuristics. The Judgment that results from this comparison is labelled negative disconfirmation if the product is worse than expected, positive disconfirmation if the product is better than expected and simple confirmation if as expected. The expectation level provides a baseline around which disconfirmation judgments are made: The higher (lower) one's expectation, the higher (lower) the subsequent satisfaction judgment, ceteris paribus. The disconfirmation effects are thought to originate from their associated emotional experiences. The delight of a positive disconfirmation enhances a satisfaction judgment, while the disappointment of a negative disconfirmation decreases it. Confirmation simply maintains the adaptation level. However, it may be instructive to consider that some consumers are more expectation influenced and some are disconfirmation influenced and some others use both as separate effects in satisfaction response (Oliver \& DeSarbo, 1988). 
Spreng et al. (1996) has incorporated role of information satisfaction to consumer satisfaction and that they have distinguished between consumer expectation and desires. American Consumer Satisfaction Index is embedded in the system of causes and effect relationships which makes it the centrepiece in a chain of relationships running from the antecedents of overall consumer satisfaction - expectations, perceived quality and value to the consequences of overall consumer satisfaction-voice (customer complaints etc.) and loyalty (Fornell et al., 1996).

According to Sachcha Vibhanga Sutra (model) and Dhamma Chakka Pavaththana Sutra (model) of Lord Buddha 2600 B.C. Sri Vachissara Thero (1969) defines suffering (extreme form of dissatisfaction) as disconfirmation between desire and perception. The definition that current author proposes i.e. Satisfaction is perception minus expectation is in line with this definition with a notable difference in using expectation in place of desire. Lord Buddha's definition of desire is "What someone likes to get" (Sri Vachissara Thero, 1969).

\section{Assimilation theory}

This theory (Hoveland et al., 1957; Olshavsky \& Miller, 1972; Anderson, 1973; Olson \& Dover, 1979) assumes that individuals are reluctant to acknowledge discrepancies from previously held positions and therefore assimilate judgment toward their initial feeling for an object or event. Thus, expectations- influenced persons would be predicted to respond with satisfaction levels similar in emotional tone to their expectations (Oliver \& DeSarbo, 1988).

\section{Attribution theory}

Weiner (1985) assumes outcomes that can be constructed as success or failures (good, bad purchases) elicit causality inferences along the three dimensions of (1) locus of causality (internal versus external) (2) stability (variability) of the cause of the outcome and (3) controllability. Internally caused outcomes are attributed to ability or effort and externally caused outcomes are attributed to many factors such as task difficulty and luck. Success is more attributed to internal causes while failures are attributed to external causes (Oliver \& DeSarbo, 1988).

\section{Equity theory}

This theory assumes that consumers are satisfied when his/her outcome-to-input ratio is proportionate to that of his partner (Harris, 1983; Oliver \& DeSarbo, 1988).

$$
\begin{gathered}
{\left[\frac{O}{I}\right]_{C} \propto\left[\frac{O}{I}\right]_{P}} \\
\text { O - Outcome } \\
\text { I }- \text { Input } \\
\text { C }- \text { Consumer } \\
\text { P }- \text { Partner }
\end{gathered}
$$

\section{Fairness}

In their study Oliver and Swan (1989) find that retail transaction satisfaction may differ in substantive ways from the subject-peer and worker-co-worker comparisons in other 
disciplines and that models of interpersonal satisfaction in the sales transaction should include mediating effect of the fairness dimension of equity. Fairness requires that outcomes and inputs be in rough approximation of one another and it can be viewed as a positive function of outcomes and negative function of inputs: i.e., the greater the respective outcome and fewer the respective inputs (costs), fair the salesperson in transaction. Their study shows preference that the inequity is in one's favour or over compensation is preferred does not have significant impact on satisfaction.

\section{Contrast theory}

As for Anderson (1973) this theory predicts that product performance above expectations will be rated very high and below expectations will be rated very poor, which means that consumers magnify ratings in the direction of the disconfirmation. Thus the disconfirmationinfluenced individuals respond quite differently than expectation-influenced individuals if these response tendencies operate as described (Oliver \& DeSarbo, 1988).

\section{Performance}

Performance response tendency considers determining if the performance is able to overwhelm the psychological response tendencies discussed.

Oliver and DeSarbo (1988) find that disconfirmation and performance may operate in tandem, and that individuals can respond separately for two concepts even though they appear to be related from a definitional standpoint. The joint operation of the two variables probably occurs because performance is an objective variable whereas disconfirmation is subject to psychological interpretation. In their study, individual analysis has shown two groups (1) who use disconfirmation experience as a major determinant and (2) who mix disconfirmation with performance and to a lesser extent with expectation in their judgment. Voss et al. (1998) found that when price and performance are consistent, expectations have an assimilation effect on performance and satisfaction judgements; when price and performance are inconsistent, expectations have no effect on satisfaction judgements.

\section{Expected waiting time}

According to Spreng et al. (1996) expectations are beliefs about the likelihood that a product is associated with certain attributes, benefits, or outcomes, whereas desires are evaluations of the extent to which those attributes, benefits, or outcomes lead to the attainment of a person's values. Expectations are future oriented and relatively malleable, whereas desires are present oriented and relatively stable.

Expectation has two levels, the upper level being the desired level and the lower level being the adequate level and in between the zone of tolerance (Zeithaml et al., 1993). However, there is no clear agreement in the literature (Teas, 1993, 1994; Parasuraman, et al., 1994) and the definition of expectation is at a question. Expectation in the case of waiting time is expected waiting time and it is interesting to find out what actually is the expected waiting time. Is it predicted waiting time or is it the acceptable waiting time or is it something else? Adequate level in the case of waiting time is the acceptable waiting time.

\section{Prior predicted waiting time}

Prior Predicted waiting time is the predicted waiting time before the arrival at the service facility. This is in fact previously held judgment about expected waiting time. Antecedents or 
determinants of prior predicted waiting time are past experience, explicit service promises, implicit service promises and word of mouth communication (Zeithaml et al., 1991; Pruyn \& Smidts, 1993; Smidts \& Pruyn, 1994; Zeithaml \& Bitner, 2003). Pruyn and Smidts (1993) may have adopted antecedents of predicted service of Zeithaml et al.'s (1991) expectation model for time prediction. Experience gained from previous visits or very similar situations helps customers to predict how long they will have to wait for the service. Advertising and appointments are examples of explicit promises (Pruyn \& Smidts, 1993). Price and tangibles associated with the service are some of the implicit service promises. Personal and nonpersonal statements made by parties other than the organization about how long it takes to complete the service and how long customer will have to wait helps customers make prior predictions about the waiting times .

\section{Posterior predicted waiting time}

The concept of posterior predicted waiting time is a new construct proposed by two authors (Pruyn \& Smidts, 1993; Smidts \& Pruyn, 1994) and they have defined posterior predicted waiting time as the adjusted predicted waiting time upon arrival at the service facility with the current queue or waiting information. This waiting time is defined as the 'will expectation' and not a 'should expectation'. It states what probably will happen at the service encounter.

\section{Perceived waiting duration}

Time duration that the customer feels he has been waiting for the service is called the perceived waiting time. According to Maister (1985), perceived waiting time depends on many factors such as whether the customer is occupied or not, waiting stage, whether the customer is anxious or not, whether the wait is certain or not, whether reason for the wait is explained or not, whether the customer is alone or not and finally the value of the service. Pruyn and Smidts (1993) and Smidts and Pruyn (1994) have named this duration as subjective waiting time as against the objective waiting duration which is the actual waiting duration the customer has been waiting. Many other researchers (Larson, 1987; Davis, 1991; Katz et al., 1991; Taylor, 1994; Carmon et al., 1995; Lerclec et al., 1995; Hui \& Tsc, 1996; Jones \& Peppiatt, 1996; Moreau, 1999; Looy et al., 1998; Diaz \& Ruiz, 2002) have evaluated customer's perceived waiting duration.

\section{Acceptable waiting time}

Pruyn and Smidts (1993) define acceptable waiting time in line with adequate service level and zone of tolerance as proposed by Zeithaml et al. (1991) and Zeithaml and Bitner (2003). According to this definition Acceptable waiting time is the difference between ideal waiting time and the maximum tolerable waiting time and it provides zone of tolerance. However, when customers are asked to state how long is the acceptable waiting time for you; customers give the maximum tolerance waiting time as the acceptable waiting time. Therefore it is better to define acceptable waiting time as the maximum tolerable waiting time. The time between acceptable waiting time and the desired waiting time is the zone of tolerance. This definition puts adequate service level corresponds to acceptable waiting time and the desired service level corresponds to desired waiting time.

Katz et al. (1991) considered the notion of reasonable waiting time. Many customers said that their concept of 'reasonable' varied based on when they came to the bank (service 
setting). Question is whether the acceptable waiting time is same as the reasonable waiting time or is there any difference.

\section{Conceptual Model}

Let us consider the definition of dependent variable Satisfaction/Dissatisfaction.

Satisfaction/Dissatisfaction $=$ Expectation - Perception, where perception is performance.

Now the question is which is more important in explaining satisfaction. Is it expectation? Is it performance? Survey of literature does not provide a definite answer to this research question. One school of thought argues in favour of expectation disconfirmation model. They say that some customers are expectation oriented, some are disconfirmation oriented. Also it is believed that disconfirmation is a stronger factor. Another school of thought argue in favour of perception model. Aim of this study is to resolve this dispute. This study therefore attempt to find whether disconfirmation is the most important factor in explaining satisfaction/ dissatisfaction. In particular, study attempts to test following research questions. To measure expectation, expected waiting time is used and to measure perception perceived waiting time is used.

Q1. Does disconfirmation explains Satisfaction/Dissatisfaction better than expectation and perception?

Q2. Can we define expectation as prediction?

Q3. Can we define expectation as adequate (acceptable) service?

Therefore, following hypotheses are drawn for testing.

\section{Hypothesis 1:}

Disconfirmation explains Satisfaction/Dissatisfaction more than expectation therefore the disconfirmation is the most important variable in explaining Satisfaction/Dissatisfaction.

\section{Hypothesis 2:}

Customers are more interested in what they have to receive compared to what they already have. Therefore the following hypothesis can be stated.

Perception does not explain Satisfaction/Dissatisfaction.

\section{Definition of expectation}

Is expected service equal to predicted service? If so is it prior predicted service or is it posterior predicted service? or is it adequate service? This situation draws hypotheses 3,4 , and 5 as follows.

\section{Hypothesis 3:}

Expected service is different from prior predicted service.

\section{Hypothesis 4:}

Expected service is different from posterior predicted service.

\section{Hypothesis 5:}

Expected service is different from acceptable service. 


\section{Methodology}

Data for this study is taken from a study on managing perception of waiting that included 53 variables. It is a cross sectional study which covered 12 services. In the study, in addition to other variables, customers were asked to state such times as Expected Waiting Time, Perceived Waiting Time, Acceptable Waiting Time, Prior Predicted Waiting Time, Posterior Predicted Waiting Time and Satisfaction with the service. These times were measured in the continuous scale. Satisfaction was measured in the following 9 point bipolar scale.

Very High 4, Quite High 3, Somewhat High 2, Slightly High 1, Neither High nor Low 0, Slightly Low -1, Somewhat Low -2, Quite Low -3, Very Low -4.

\section{Results}

Table 1 shows that disconfirmation explains $14.2 \%$ of satisfaction where as expected waiting time explains $7.2 \%$ of satisfaction. In contrast, perceived waiting time explains $1.5 \%$ of satisfaction. These results lead to the acceptance of the hypothesis that disconfirmation is the most important variable in explaining satisfaction. Second most important variable in explaining satisfaction is expected waiting time.

Table 1: Dependent Variable: Satisfaction

\begin{tabular}{|c|c|c|c|c|c|c|}
\hline Variable & $\begin{array}{c}\text { R } \\
\text { Square }\end{array}$ & $\begin{array}{l}\text { R Square } \\
\text { Adjusted }\end{array}$ & $\begin{array}{c}\text { Std } \\
\text { Error }\end{array}$ & $\begin{array}{l}\text { Degrees of } \\
\text { Freedom } \\
\text { ( Regression/ } \\
\text { Residual) }\end{array}$ & F statistic & Significance \\
\hline Expected Waiting Time & 0.074 & 0.072 & 2.2349 & $1 / 405$ & 32.466 & 0.000 \\
\hline Perceived Waiting Time & 0.017 & 0.015 & 2.30302 & $1 / 405$ & 6.999 & 0.008 \\
\hline Disconfirmation & 0.144 & 0.142 & 2.14880 & $1 / 405$ & 68.263 & 0.000 \\
\hline
\end{tabular}

Table 2: Comparison of Means: Expected waiting time and prior predicted waiting time

\begin{tabular}{|c|c|c|c|c|c|c|c|c|}
\hline \multicolumn{9}{|l|}{ Paired Samples Test } \\
\hline \multirow{3}{*}{ Pair } & \multicolumn{5}{|c|}{ Paired Differences } & \multirow{3}{*}{$\mathbf{t}$} & \multirow{3}{*}{ df } & \multirow{3}{*}{$\underset{\text { (2-tailed) }}{\text { Sig. }}$} \\
\hline & \multirow[t]{2}{*}{ Mean } & \multirow[t]{2}{*}{$\begin{array}{c}\text { Std. } \\
\text { Deviation }\end{array}$} & \multirow{2}{*}{$\begin{array}{l}\text { Std. } \\
\text { Error } \\
\text { Mean }\end{array}$} & \multicolumn{2}{|c|}{$\begin{array}{l}95 \% \text { Confidence } \\
\text { Interval of the } \\
\text { Difference }\end{array}$} & & & \\
\hline & & & & Lower & Upper & & & \\
\hline $\begin{array}{l}\text { Expected Waiting } \\
\text { Time - Prior Pre- } \\
\text { dicted Waiting Time }\end{array}$ & -1.69730 & 10.97449 & .54332 & -2.76536 & -.62924 & -3.124 & 407 & .002 \\
\hline
\end{tabular}

Comparison of means of Expected waiting time and Prior predicted waiting time is presented in table 2. Two tailed significance of 0.002 shows that expected waiting time is significantly different from prior predicted waiting time. Similarly, table 3 with two tailed significance of 0.001 shows that expected waiting time is different from posterior predicted waiting time. 
Table 3: Comparison of Means: Expected waiting time and posterior predicted waiting time

\begin{tabular}{|c|c|c|c|c|c|c|c|c|}
\hline \multicolumn{9}{|l|}{ Paired Samples Test } \\
\hline \multirow{3}{*}{ Pair 1} & \multicolumn{5}{|c|}{ Paired Differences } & \multirow{3}{*}{$\mathbf{t}$} & \multirow{3}{*}{ df } & \multirow{3}{*}{$\begin{array}{c}\text { Sig. } \\
\text { (2-tailed) }\end{array}$} \\
\hline & \multirow[t]{2}{*}{ Mean } & \multirow[t]{2}{*}{$\begin{array}{c}\text { Std. } \\
\text { Deviation }\end{array}$} & \multirow[t]{2}{*}{$\begin{array}{c}\text { Std. Error } \\
\text { Mean }\end{array}$} & \multicolumn{2}{|c|}{$\begin{array}{l}95 \% \text { Confidence } \\
\text { Interval of the } \\
\text { Difference } \\
\end{array}$} & & & \\
\hline & & & & Lower & Upper & & & \\
\hline $\begin{array}{l}\text { Expected Waiting } \\
\text { Time - Posterior Pre- } \\
\text { dicted Waiting Time }\end{array}$ & -2.63603 & 15.48314 & .76653 & -4.14288 & -1.12918 & -3.439 & 407 & .001 \\
\hline
\end{tabular}

Results of table 4 shows mean difference of expected waiting time and acceptable waiting time and two tailed significance of 0.003 shows that expected waiting time is different from acceptable waiting time.

Table 4: Comparison of Means: Expected Waiting time and Acceptable Waiting Time

\begin{tabular}{|c|c|c|c|c|c|c|c|c|}
\hline \multicolumn{9}{|c|}{ Paired Samples Test } \\
\hline \multirow{3}{*}{ Pair } & \multicolumn{5}{|c|}{ Paired Differences } & \multirow{3}{*}{$\mathbf{t}$} & \multirow{3}{*}{ df } & \multirow{3}{*}{$\begin{array}{c}\text { Sig. } \\
\text { (2-tailed) }\end{array}$} \\
\hline & \multirow[t]{2}{*}{ Mean } & \multirow[t]{2}{*}{$\begin{array}{c}\text { Std. } \\
\text { Deviation }\end{array}$} & \multirow[t]{2}{*}{$\begin{array}{c}\text { Std. Error } \\
\text { Mean }\end{array}$} & \multicolumn{2}{|c|}{$\begin{array}{l}\text { 95\% Confidence } \\
\text { Interval of the } \\
\text { Difference }\end{array}$} & & & \\
\hline & & & & Lower & Upper & & & \\
\hline $\begin{array}{l}\text { Expected Waiting } \\
\text { Time - Accept- } \\
\text { able Waiting Time }\end{array}$ & 1.48529 & 9.98025 & .49410 & .51400 & 2.45659 & 3.006 & 407 & .003 \\
\hline
\end{tabular}

\section{Conclusions}

The results of the study show that the disconfirmation is the most important variable in determining customer satisfaction/dissatisfaction followed by expectation. Influence of perception on satisfaction/dissatisfaction is negligible. These findings support scholars who favour disconfirmation paradigm over perception paradigm. Implication for management practitioner is that they should concentrate on finding what the customer did not get first and then find what the customer expectations are next. What they already have given has little bearing on customer satisfaction and, therefore, pay more attention to customer expectation. Disconfirmation hurts the customer more and that should be given priority in service/product planning.

Next finding of the study is that expected time is different from prior predicted, posterior predicted and acceptable waiting time. This means expected service is neither predicted service nor is adequate service. Further research is needed to ascertain the definition of expected service: Most probably it should be desired service. According to Lord Buddha (2600 B.C.) desire is defined as what someone like to get. 


\section{References}

Anderson, R. E. (1973). Consumer Dissatisfaction: The effect of disconfirmed expectancy on perceived product performance. Journal of Marketing Research, 10, 38-44.

Carmon, Z., Shanthikumar, J.G., \& Carmon, T.F. (1995). A Psychological Perspective on Service Segmentation Models: The significance of accounting for consumers' perceptions of waiting and service. Management Science, 4(11), 1806-1815.

Cronin, J. J. \& Taylor, S.A. (1994). SERVPERF vs SERVQUAL: Reconciling performance based and perceptions-minus-expectations measurement of service quality. Journal of Marketing, 58(1), 125-131.

Davis, M. M. (1991). How Long Should a Customer Wait for a Service? Decision Sciences, 22(2), 421-434.

Davis, M. M. \& Heineke, J. (1998). How Disconfirmation, Perception and Actual Times Impact Customer Satisfaction. International Journal of Service Industry Management, 9(1), 64-73.

Diaz, A. B. C. \& Ruiz, F. J. M. (2002). The Consumer's Reactions to Delay in Service. International Journal of Service Industry Management, 13(2), 118-140.

Fornell, C., Johnson M. D., Anderson, E. W., Cha, J., \& Bryant, B.E. (1996). The American Customer Satisfaction Index: Nature, purpose, and findings. Journal of Marketing, 60(4), 7-18.

Harris R. J. (1983). Pining Down the Equity Formula. In D. M. Messick and K. S.Cook (Eds.), Equity Theory: Psychological and sociological perspectives (pp. 207-241). New York: Praeger.

Hoveland, C. I., Harvey, O. J., \& Muzafer, S. (1957). Assimilation and Contrast Effects in Reactions to Communication and Attitude Change. Journal of Abnormal and Social Psychology, 55(2), 244-252.

Hui, M. K. \& Tse, D. K. (1996). What to Tell Consumers in Waits of Different Lengths: An integrative model of service evaluation. The Journal of Marketing, 60 (2) 81-90.

Ilgen, D. R. (1971). Satisfaction with Performance as a Function of the Initial Level of Expected Performance and the Deviation from Expectations. Organizational Behavior and Human Performance, 6(3), 345-361.

Jones, P. \& Peppiatt, E. (1996). Managing Perception of Waiting Times in Service Queues. International Journal of Service Industry Management, 7(5), 47-61.

Katz, K., Larson, B., \& Larson R. (1991). Prescriptions for the Waiting in Line Blues: Entertain, enlighten and engage, Sloan Management Review, 32(2), 44-53.

Larson, R. (1987). Perspectives on Queue: Social justice and psychology of queuing. Journal of Operations Research, 35(6), 896-905.

Lerclec, F., Schmidt, B., \& Dubé, I. (1995). Waiting Time and Decision Making: Is time like money? Journal of Consumer Research, 22 (1), 110-119.

Looy, B. V., Dierdonck, R. V., \& Gemmel, P. (1998). Services Management: An integrated approach. New Jersey: Financial Times Pitman Publishing.

Maister, D. H. (1985). The Psychology of Waiting Lines. In J. A. Czepiel, M. R. Solomon and C. F. Surprenant (Eds.) The Service Encounter: Managing employee/customer interaction in service businesses (pp. 113- 123). Lexington, MA: Lexington Books.

Moreau, A. D. (1999). Waiting for Services: Ten years of empirical research. International Journal of Service Industry Management, 10 (10), 170-188. 
Oliver, R. L. (1980). A Cognitive Model of the Antecedents and Consequences of Satisfaction Decisions. Journal of Marketing Research, 17(4), 460-469.

Oliver, R. L. \& DeSarbo, W. S. (1988). Response Determinants in Satisfaction Judgments. Journal of Consumer Research, 14(4), 495-507.

Oliver, R. L. \& Swan, J. E. (1989). Consumer Perception of Interpersonal Equity and Satisfaction in Transactions. Journal of Marketing, 53(2), 21-35.

Olshavsky, R. W. \& Miller, J. A. (1972). Consumer Expectations, Product Performance, and Perceived Product Quality, Journal of Marketing Research, 9(1), 19-21.

Olson, J. C. \& Dover, P. (1979). Disconfirmation of Consumer Expectations Through Product Trial. Journal of Applied Psychology, 64(2), 179-189.

Parasuraman, A., Zeithaml, V. A., \& Berry, L. L. (1994). Reassessment of Expectation as a Comparison Standard on Measuring Service Quality: Implications for future research. Journal of Marketing, 58(1), 111-124.

Pruyn, A. \& Smidts, A. (1993). Customers' Evaluations of Queues: Three exploratory studies. European Advances in Consumer Research, 1, 371-382.

Smidts, A. \& Pruyn, A. (1994). How Waiting Time Affects Customers Satisfaction with Service: The role of subjective variables. Proceedings of the 3rd International Seminar in Services Management, Université d' Aix-Marseille, 678-696.

Spreng, R. A., MacKenzie, S. B., \& Olshavsky, R. W. (1996). A Reexamination of the Determinants of Consumer Satisfaction. The Journal of Marketing, 60, 15-32.

Sri Vachissara Thero, D. (1969). Great Pirith Book. Colombo: Gunasena Publishers.

Taylor, S. (1994). Waiting for Service: The relationship between delays and evaluation of service. Journal of Marketing, 58(2), 56-69.

Teas, R. K. (1993). Expectations, Performance Evaluation and Consumers' Perception of Quality. Journal of Marketing, 57(4), 18-34.

Teas, R. K. (1994). Expectations as a Comparison Standard in Measuring Service Quality: An assessment of a reassessment. Journal of Marketing, 58(1), 132-139.

Voss, G. B., Parasuraman, A., \& Grewal, D. (1998). The Role of Price, Performance, and Expectations in Determining Satisfaction in Service Exchanges. Journal of Marketing, October, 46-61.

Weaver, D. \& Brickman, P. (1974). Expectancy Feedback and Disconfirmations Independent Factors in Outcome Satisfaction. Journal of Personality and Social Psychology, 30(3), 420-428.

Weiner, B. (1985). An Attributional Theory of Motivation and Emotions. Psychological Review, 92(4), 548-573.

Zeithaml, V. A. \& Bitner, M. J. (2003). Services Marketing. New Delhi: Tata McGraw-Hill Edition.

Zeithaml, V. A., Berry, L. L., \& Parasuraman, A. (1991). The Nature and Determinants of Customer Expectations of Service. Marketing Science Research Program Series, May Report, 91-113.

Zeithaml, V. A., Berry, L. L., \& Parasuraman, A. (1993). The Nature and Determinants of Customer Expectations of Service. Journal of the Academy of Marketing Science, 21(1), 1-12. 